\title{
Response: Commentary: Manifold Routes to a Nucleus
}

\author{
Anthony M. Poole ${ }^{1 *}$ and Heather L. Hendrickson ${ }^{2}$ \\ ${ }^{1}$ School of Biological Sciences, University of Auckland, Auckland, New Zealand, ${ }^{2}$ School of Natural and Computational \\ Sciences, Massey University, Auckland, New Zealand
}

Keywords: planctomycetes, nucleus, compartmentation, Gemmata obscuriglobus, eukaryogenesis

\section{A Commentary on}

Commentary: Manifold Routes to a Nucleus

by Jogler, C., Wiegand, S., and Devos, D. P. (2019). Front. Microbiol. 10:1198. doi: 10.3389/fmicb.2019.01198

\section{OPEN ACCESS}

Edited by:

John R. Battista,

Louisiana State University,

United States

Reviewed by:

Gary M. King,

Louisiana State University,

United States

Graham Charles Walker,

Massachusetts Institute of Technology, United States

*Correspondence:

Anthony M. Poole

a.poole@auckland.ac.nz

Specialty section:

This article was submitted to

Evolutionary and Genomic

Microbiology,

a section of the journal

Frontiers in Microbiology

Received: 06 August 2019

Accepted: 24 October 2019

Published: 08 November 2019

Citation:

Poole AM and Hendrickson HL (2019)

Response: Commentary: Manifold

Routes to a Nucleus.

Front. Microbiol. 10:2585.

doi: 10.3389/fmicb.2019.02585
In a recent paper published in this journal (Hendrickson and Poole, 2018), we discussed and explored the evolutionary implications of emerging observations from prokaryotic systems, where forms of genetic compartmentation have been identified or proposed (Fuerst and Sagulenko, 2011; Sagulenko et al., 2014; Spang et al., 2015; Chaikeeratisak et al., 2017a,b; Zaremba-Niedzwiedzka et al., 2017). Our main aim was to consider how these observations might help shed light on the question of the origin of the eukaryote nucleus. The issue for understanding the origin of the nucleus is that it can be tricky to work on something that appears to be a singular event in evolution. This is because there is a temptation to view singular events as necessitating some type of special circumstance or one-off mechanism. Our paper aimed to address this by indicating how a range of data emerging from the study of diverse prokaryote systems might provide insight into the origins of the eukaryote nucleus, not because of a direct evolutionary relationship with eukaryotes but because they suggest that compartmentation of genetic material may not have evolved only once in the history of life. This in turn opens up the question of the origin of eukaryote nucleus to a much a broader question: what might drive the evolution of genetic compartmentation?

Jogler et al. (2019) recently published a commentary in response to our paper in which they took no issue with any of the key points of our paper. Instead, they criticized the way we discussed results concerning the fascinating bacterium, Gemmata obscuriglobus, and cited additional references, mostly from their own labs. G. obscuriglobus is relevant to our discussion of genetic compartmentation because it is the best-studied member of a phylum with members that have been reported as possessing a compartment with similarities to the eukaryote nucleus (Fuerst, 2005; Lee et al., 2009; Fuerst and Sagulenko, 2011; Sagulenko et al., 2014). In addition, other publications have reported features of G. obscuriglobus that are normally associated with eukaryotes, including endocytosis-like processes (Lonhienne et al., 2010), the separation of transcription and translation (Gottshall et al., 2014), and the presence of structures that resemble the nuclear pore complex (Sagulenko et al., 2017). We acknowledged that the issue of whether there is a nucleus-like compartment in Gemmata and related bacteria is a "matter of ongoing debate" and respectfully disagree with Jogler and colleagues' conclusion (Jogler et al., 2019) that this possibility has been disproven. For example, while one electron tomography study (Acehan et al., 2014) using plastic embedding concluded that G. obscuriglobus is neither compartmentalized or nucleated, a subsequent cryo-electron tomography study from an independent group (Sagulenko et al., 2014) supported compartmentalization. Similarly, Jogler and colleagues' claim (Jogler et al., 2019) that structures from the internal membrane of Gemmata that resemble the eukaryote nuclear pore complex (Sagulenko et al., 2017) 
are instead crateriform structures found on the exterior of G. obscuriglobus cannot account for the observations that proteins associated with these pores are exclusive to inner membranes (Sagulenko et al., 2017), and that antibodies raised against them are both specific and localized exclusively to the inner membranes. The field is still working toward a full characterization and understanding of the unusual membrane architecture (and associated biology) of Gemmata so it is premature to refer to a paradigm shift as having taken place.

With characterization of the cellular architecture of this fascinating bacterium a subject of ongoing research, we are open to data that could show that Jogler and colleagues' interpretation is partially or even wholly correct. However, given the main focus of our paper, there seems to be limited value in weighing in on extensive debate on this topic when it was not germane to the primary point of our article. Indeed, the key point of our paper is wholly unaffected by Jogler and colleagues' concerns. It would have been utterly remiss of us to have discussed non-eukaryotic

\section{REFERENCES}

Acehan, D., Santarella-Mellwig, R., and Devos, D. P. (2014). A bacterial tubulovesicular network. J. Cell Sci. 127, 277-280. doi: 10.1242/jcs.137596

Chaikeeratisak, V., Nguyen, K., Egan, M. E., Erb, M. L., Vavilina, A., and Pogliano, J. (2017a). The phage nucleus and tubulin spindle are conserved among large pseudomonas phages. Cell Rep. 20, 1563-1571. doi: 10.1016/j.celrep.2017.07.064

Chaikeeratisak, V., Nguyen, K., Khanna, K., Brilot, A. F., Erb, M. L., Coker, J. K., et al. (2017b). Assembly of a nucleus-like structure during viral replication in bacteria. Science 355, 194-197. doi: 10.1126/science.aal2130

Fuerst, J. A. (2005). Intracellular compartmentation in planctomycetes. Annu. Rev. Microbiol. 59, 299-328. doi: 10.1146/annurev.micro.59.030804.121258

Fuerst, J. A., and Sagulenko, E. (2011). Beyond the bacterium: planctomycetes challenge our concepts of microbial structure and function. Nat. Rev. Microbiol. 9, 403-413. doi: 10.1038/nrmicro2578

Gottshall, E. Y., Seebart, C., Gatlin, J. C., and Ward, N. (2014). Spatially segregated transcription and translation in cells of the endomembranecontaining bacterium Gemmata obscuriglobus. Proc. Natl. Acad. Sci. U.S.A. 111, 11067-11072. doi: 10.1073/pnas.1409187111

Hendrickson, H. L., and Poole, A. M. (2018). Manifold routes to a nucleus. Front. Microbiol. 9:2604. doi: 10.3389/fmicb.2018.02604

Jogler, C., Wiegand, S., and Devos, D. P. (2019). Commentary: manifold routes to a nucleus. Front. Microbiol. 10:1198. doi: 10.3389/fmicb.2019.01198

Lee, K. C., Webb, R. I., Janssen, P. H., Sangwan, P., Romeo, T., Staley, J. T., et al. (2009). Phylum Verrucomicrobia representatives share a compartmentalized cell plan with members of bacterial phylum Planctomycetes. BMC Microbiol. 9:5. doi: 10.1186/1471-2180-9-5 cases of genetic compartmentation and completely ignored the extensive literature on Gemmata.

\section{AUTHOR CONTRIBUTIONS}

All authors listed have made a substantial, direct and intellectual contribution to the work, and approved it for publication.

\section{FUNDING}

$\mathrm{AP}$ and $\mathrm{HH}$ acknowledge funding from Royal Society $\mathrm{Te}$ Apārangi (New Zealand), grant number MAU18-009. The funder had no role in study design, data collection and analysis, decision to publish, or preparation of the manuscript.

\section{ACKNOWLEDGMENTS}

We thank the editor and both reviewers for helpful comments and advice.

Lonhienne, T. G., Sagulenko, E., Webb, R. I., Lee, K. C., Franke, J., Devos, D. P., et al. (2010). Endocytosis-like protein uptake in the bacterium Gemmata obscuriglobus. Proc. Natl. Acad. Sci. U.S.A. 107, 12883-12888. doi: $10.1073 /$ pnas. 1001085107

Sagulenko, E., Morgan, G. P., Webb, R. I., Yee, B., Lee, K. C., and Fuerst, J. A. (2014). Structural studies of planctomycete Gemmata obscuriglobus support cell compartmentalisation in a bacterium. PLoS ONE 9:e91344. doi: 10.1371/journal.pone.0091344

Sagulenko, E., Nouwens, A., Webb, R. I., Green, K., Yee, B., Morgan, G., et al. (2017). Nuclear pore-like structures in a compartmentalized bacterium. PLoS ONE 12:e0169432. doi: 10.1371/journal.pone.0169432

Spang, A., Saw, J. H., Jørgensen, S. L., Zaremba-Niedzwiedzka, K., Martijn, J., Lind, A. E., et al. (2015). Complex archaea that bridge the gap between prokaryotes and eukaryotes. Nature 521, 173-179. doi: 10.1038/nature14447

Zaremba-Niedzwiedzka, K., Caceres, E. F., Saw, J. H., Bäckström, D., Juzokaite, L., Vancaester, E., et al. (2017). Asgard archaea illuminate the origin of eukaryotic cellular complexity. Nature 541, 353-358. doi: 10.1038/nature21031

Conflict of Interest: The authors declare that the research was conducted in the absence of any commercial or financial relationships that could be construed as a potential conflict of interest.

Copyright (C) 2019 Poole and Hendrickson. This is an open-access article distributed under the terms of the Creative Commons Attribution License (CC BY). The use, distribution or reproduction in other forums is permitted, provided the original author(s) and the copyright owner(s) are credited and that the original publication in this journal is cited, in accordance with accepted academic practice. No use, distribution or reproduction is permitted which does not comply with these terms. 